\title{
Kajian Signifikansi Lanskap Permukiman Tradisional Pekon Hujung, Lampung Barat
}

\author{
Rian Adetiya Pratiwi ${ }^{1 *}$, Rizka Nabilah ${ }^{1}$, Goldie Melinda Wijayanti² \\ 1. Prodi Arsitektur Lanskap, ITERA, Jl. Terusan Ryacudu, Way Huwi, Kec. Jati Agung, Kabupaten \\ Lampung Selatan, Lampung, Indonesia \\ 2. Prodi Perencanaan Wilayah dan Kota, ITERA, Jl. Terusan Ryacudu, Way Huwi, Kec. Jati Agung, \\ Kabupaten Lampung Selatan, Lampung, Indonesia \\ E-mail: rian,pratiwi@arl.itera.ac.id
}

\begin{abstract}
Study of Landscape Significance in Pekon Hujung Traditional Settlement, Lampung Barat. Pekon Hujung is a traditional settlement located in Belalau District, West Lampung Regency and directly adjacent to South Oku, South Sumatra Province that describes the character of the Lampungnese people. The rapid pace of urban development and modernization can shift the cultural values that exist in a traditional settlement and its environment. One of the negative impacts that may arise is the loss of cultural importance in a traditional settlement area. An assessment of the importance or significance of a culture can be carried out as one way of determining an appropriate conservation strategy. This study was conducted to identify and to analyze the key characters that formed Pekon Hujung cultural landscape. The method used in this study is the Cultural Heritage Landscape Assessment (CHLA) which is used to assess the significance or importance of a landscape. The assessment resulted in important value score of 27, which was cllassified as high category of the landscape importance. In general, Pekon Hujung has distinctive character, where the supporting elements, as well as the people still live and carry out the cultural values that have existed since long ago. The Pekon Hujung landscape is a culture that has important values and local wisdom which can still be applied in today's life.
\end{abstract}

Keywords: Cultural Heritage Landscape Assessment, cultural landscape character, landscape character assessment, landscape signification, Pekon Hujung

\section{Pendahuluan}

Keragaman budaya di provinsi lampung terbentuk dari keberadaan dua suku, yaitu ulun Lampung Pepadun atau masyarakat Lampung Pepadun dan ulun Lampung Saibatin atau masyarakat Lampung Saibatin. Perbedaan dari kedua golongan suku ini dapat dilihat dari area permukimannya, masyarakat Lampung Pepadun biasanya mendiami wilayah pegunungan sementara masyarakat Lampung Saibatin umumnya di wilayah pesisir. Keragaman wilayah tinggal inilah yang pada akhirnya memberikan ciri tersendiri bagi setiap permukiman tradisional di masing-masing daerah (Pratiwi dan Gunawan, 2017).

Pekon Hujung merupakan salah satu permukiman tradisional yang terletak di Kecamatan Belalau, Kabupaten Lampung Barat dan berbatasan langsung dengan Oku Selatan Provinsi Sumatera Selatan. Pekon atau kawasan perdesaan adalah suatu kawasan permukiman dengan kegiatan utama pertanian, termasuk pengelolaan sumber daya alam dengan susunan fungsi kawasan sebagai tempat permukiman perdesaan, pelayanan jasa pemerintahan, pelayanan sosial, dan kegiatan ekonomi (Peraturan Daerah Kabupaten Lampung Barat Nomor 1, 2012). Secara administratif, Pekon Hujung merupakan satu dari sepuluh desa/kelurahan yang terdapat di Kecamatan Belalau (Badan Pusat Statistik Kabupaten Lampung Barat, 2019). Pekon Hujung berpenduduk sekitar 6000 jiwa dengan 1300 kepala keluarga, masih menggunakan rumah khas yang disebut sebagai lamban bermaterial kayu (Lestari dan Fadhili, 2020).

Laju perkembangan dan modernisasi kota yang terjadi secara cepat dapat menggeser nilai-nilai budaya yang ada pada suatu permukiman tradisional dan lingkungannya. Pembangunan yang pesat dapat memberikan dampak negatif dan positif pada lingkungan. Salah satu dampak negatif yang mungkin muncul adalah hilangnya nilai-nilai penting budaya pada suatu kawasan permukiman tradisional. Penilaian nilai penting atau signifikansi suatu lanskap budaya dapat dilakukan sebagai salah satu cara untuk menentukan strategi pelestarian yang sesuai. Menurut Tanudirjo (2004) dalam Malim, D.D.L.O., Sumantri, I., Tahara, T 
(2019), nilai penting budaya dapat bersifat lokal, nasional, regional, serta internasional. Nilai budaya lokal memiliki nilai penting bagi sekelompok masyarakat yang tinggal di daerah setingkat desa, kabupaten, atau provinsi, namun tidak memiliki nilai bagi masyarakat di luar kawasan tersebut. Nilai budaya nasional memiliki nilai yang diakui oleh seluruh masyarakat nusantara. Nilai budaya regional adalah nilai yang diakui penting bagi masyarakat di beberapa negara. Sedangkan nilai budaya internasional adalah nilai yang diakui oleh seluruh dunia. Lanskap permukiman tradisional Pekon Hujung merupakan lanskap budaya yang memiliki nilai penting lokal karena merupakan lanskap yang menggambarkan karakter masyarakat Lampung. Pengetahuan dan pemahaman terkait nilai penting diperlukan sebagai upaya untuk mempertahankan dan meningkatkan karakter lanskap. Penelitian ini dilakukan untuk mengidentifikasi dan menganalisis karakter kunci pembentuk lanskap budaya Pekon Hujung sehingga hasilnya dapat digunakan untuk menentukan tindakan konservasi dan pengelolaan yang tepat.

\section{Metode}

\subsection{Lokasi dan Waktu Penelitian}

Penelitian ini dilakukan di Pekon Hujung, Kabupaten Lampung Barat, Provinsi Lampung. Penelitian ini dilakukan selama tiga bulan dimulai dari Bulan Juni hingga Agustus 2020.

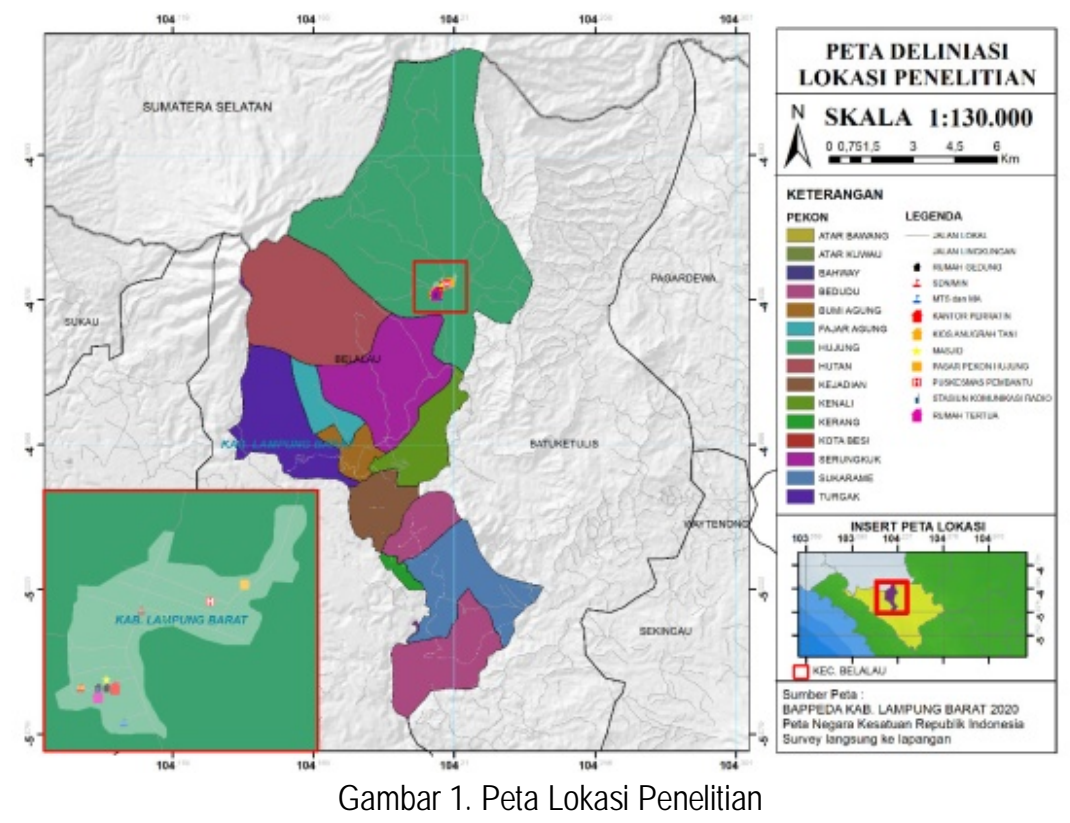

\subsection{Metode Penelitian}

Metode yang digunakan dalam penelitian ini adalah Cultural Heritage Landscape Assessment (CHLA). Metode deskriptif ini diadaptasi dari Heritage Victoria Landscape Assessment Guidelines dalam Heritage Council of Victoria (2009). Metode ini dapat digunakan untuk menilai signifikansi atau nilai penting dari suatu lanskap budaya dengan cara mendeskripsikan elemen dan karakteristik unik yang membentuk suatu lanskap budaya.

\subsection{Analisis Data}

Tahapan penilaian dengan metode CHLA adalah sebagai berikut:

1. Mengumpulkan informasi dengan melakukan studi literatur, survei lapang, sumber primer melalui wawancara tokoh adat;

2. Mengidentifikasi nilai signifikansi lanskap budaya, mengacu pada 4 kriteria menurut piagam Burra yang meliputi nilai estetika, sejarah, sosial atau spiritual, serta ilmiah (Tabel 1); dan

3. Menghitung nilai 4 kriteria dengan menggunakan metode skoring (Selamet 1983 dalam Allindani 2007) dengan rumus interval kelas: 
Interval Kelas $(\mathrm{IK})=\frac{\text { Skor Maksimum }(\text { SMa })-\text { Skor Minimum }(\mathrm{SMi})}{\text { Jumlah Kategori }}$

Tinggi $=\mathrm{SMi}+2 \mathrm{IK}+1$ sampai SMa

Sedang $=\mathrm{SMi}+\mathrm{IK}+1$ sampai $(\mathrm{SMi}+2 \mathrm{IK})$

Rendah $=$ SMi sampai SMi + IK

$\mathrm{SMa}=33$

$\mathrm{SMi}=11$

Jumlah kategori $=3$ (rendah, sedang, tinggi)

Interval kelas $=(33-11) / 3=7.333=7$ (dibulatkan)

Signifikansi Tinggi $\quad=\mathrm{SMi}+2 \mathrm{~K}+1$ sampai SMa

$=11+2(7)+1$ sampai $11+2(7)$

$=26$ sampai 33

Signifikansi sedang $\quad=\mathrm{SMi}+\mathrm{IK}+1$ sampai $(\mathrm{SMi}+2 \mathrm{IK})$

$=11+1(7)+1$ sampai $11+2(7)$

$=19$ sampai 25

Signfikansi rendah

= SMi sampai SMi + IK

$=11$ sampai $11+7$

$=11$ sampai 18

Hasil dari analisis nilai signifikansi lanskap budaya ini akan menunjukkan karakter kunci dan nilai signifikansi lanskap permukiman tradisional Pekon Hujung.

Tabel 1. Kriteria Penilaian Signifikansi Lanskap Budaya

\begin{tabular}{|c|c|c|c|c|}
\hline \multirow[t]{2}{*}{ No } & \multirow[t]{2}{*}{ Kriteria } & \multicolumn{3}{|c|}{ Skor } \\
\hline & & Rendah & Sedang & Tinggi \\
\hline \multirow[t]{4}{*}{1} & Estetikab & & & \\
\hline & $\begin{array}{l}\text { a. Arsitektur } \\
\text { rumah }\end{array}$ & $\begin{array}{l}\text { Didominasi }>50 \% \text { oleh rumah } \\
\text { bergaya arsitektur modern }\end{array}$ & $\begin{array}{l}\text { Didominasi }>50 \% \text { oleh rumah } \\
\text { semi modern tapi tetap memiliki } \\
\text { corak/ gaya tradisional }\end{array}$ & $\begin{array}{l}\text { Didominasi }>50 \% \text { oleh rumah yang } \\
\text { memiliki gaya arsitektur tradisional dan } \\
\text { keaslian }\end{array}$ \\
\hline & $\begin{array}{l}\text { b. Elemen } \\
\text { lanskap }\end{array}$ & $\begin{array}{l}\text { Keaslian elemen baik bentuk, } \\
\text { material, dan letaknya }<50 \%\end{array}$ & $\begin{array}{l}\text { Keaslian elemen baik bentuk, } \\
\text { material, dan letaknya } 50-75 \%\end{array}$ & $\begin{array}{l}\text { Keaslian elemen baik bentuk, material, } \\
\text { dan letaknya }>75 \%\end{array}$ \\
\hline & $\begin{array}{l}\text { c. Integritas/ } \\
\text { unitya }\end{array}$ & $\begin{array}{l}\text { Lanskap tidak memiliki } \\
\text { kesatuan/ unity dan } \\
\text { karakternya tidak harmonis } \\
\text { dengan lingkungan sekitar }\end{array}$ & $\begin{array}{l}\text { Lanskap memiliki unity dan } \\
\text { integritas karakter yang lemah } \\
\text { dengan sekitarnya }\end{array}$ & $\begin{array}{l}\text { Lanskap memiliki unity yang kuat dan } \\
\text { karakter yang harmonis dengan } \\
\text { sekitarnya }\end{array}$ \\
\hline \multirow[t]{4}{*}{2} & Sejarahb & & & \\
\hline & a. Land use & $\begin{array}{l}\text { Terjadi perubahan penggunaan } \\
\text { lahan }>50 \%\end{array}$ & $\begin{array}{l}\text { Terjadi perubahan penggunaan } \\
\text { lahan } 25-50 \%\end{array}$ & $\begin{array}{l}\text { Terjadi perubahan penggunaan lahan } \\
<25 \%\end{array}$ \\
\hline & $\begin{array}{l}\text { b. elemen } \\
\text { lanskap }\end{array}$ & $\begin{array}{l}\text { Terdapat hanya satu elemen } \\
\text { bersejarah dengan umur }>50 \\
\text { tahun }\end{array}$ & $\begin{array}{l}\text { Terdapat 2-5 elemen bersejarah } \\
\text { dengan umur }>50 \\
\text { tahun }\end{array}$ & $\begin{array}{l}\text { Terdapat lebih dari } 5 \text { elemen bersejarah } \\
\text { dengan umur }>50 \text { tahun }\end{array}$ \\
\hline & c. Area/ruang & $\begin{array}{l}\text { Tidak terdapat area atau } \\
\text { tempat yang memiliki nilai } \\
\text { sejarah kejadian penting di } \\
\text { masa lalu }\end{array}$ & $\begin{array}{l}\text { Terdapat area atau tempat } \\
\text { bersejarah di masa lalu namun } \\
\text { saat ini sudah berubah fungsi }\end{array}$ & $\begin{array}{l}\text { Area atau tempat berseajrah masih } \\
\text { dipertahankan dan terdapat } \\
\text { landmark/penanda }\end{array}$ \\
\hline \multirow[t]{4}{*}{3} & $\mathrm{a} / \mathrm{s}$ & & & \\
\hline & $\begin{array}{l}\text { a. Areal } \\
\text { ruanga }\end{array}$ & $\begin{array}{l}\text { Area/ruang dan aktivitas sosial } \\
\text { budaya masyarakat sudah tidak } \\
\text { ada lagi }\end{array}$ & $\begin{array}{l}\text { Aktivitas sosial budaya } \\
\text { masyarakat masih berjalan namun } \\
\text { area atau ruang untuk beraktivitas } \\
\text { sudah tidak ada atau sebaliknya }\end{array}$ & $\begin{array}{l}\text { Masih terdapat area atau tempat penting } \\
\text { bagi masyarakat dalam melakukan } \\
\text { aktivitas social budaya }\end{array}$ \\
\hline & $\begin{array}{l}\text { b. Normal } \\
\text { aturan adat }\end{array}$ & $\begin{array}{l}\text { Setidaknya masih terdapat satu } \\
\text { norma atau aturan adat } \\
\text { yang masih dijalankan oleh } \\
\text { masyarakat }\end{array}$ & $\begin{array}{l}\text { Beberapa norma atau aturan adat } \\
\text { sudah mulai ditinggalkan oleh } \\
\text { masyarakat }\end{array}$ & $\begin{array}{l}\text { Norma atau aturan adat masih } \\
\text { sepenuhnya dijalankan oleh masyarakat }\end{array}$ \\
\hline & $\begin{array}{l}\text { c. Tradisi } \\
\text { budaya }\end{array}$ & $\begin{array}{l}\text { Masyarakat sudah sepenuhnya } \\
\text { meninggalkan tradisi adat yang } \\
\text { mengandung nilai spiritual }\end{array}$ & $\begin{array}{l}\text { Nilai spiritual dalam tradisi } \\
\text { masyarakat mulai } \\
\text { menghilang/hanya dilakukan oleh } \\
\text { sebagian masyarakat }\end{array}$ & $\begin{array}{l}\text { Masyarakat umumnya masih melakukan } \\
\text { tradisi } \\
\text { ritual adat pada acara tertentu }\end{array}$ \\
\hline \multirow[t]{3}{*}{4} & IImiahb & & & \\
\hline & a. Aktivitas & $\begin{array}{l}\text { Aktivitas atau kearifan lokal } \\
\text { yang bernilai pendidikan sudah } \\
\text { hilang }\end{array}$ & $\begin{array}{l}\text { Masih terdapat aktivitas atau } \\
\text { kearifan lokal yang bernilai } \\
\text { pendidikan namun sudah mulai } \\
\text { hilang }\end{array}$ & $\begin{array}{l}\text { Terdapat kearifan lokal yang } \\
\text { dipertahankan dan berpotensi bagi } \\
\text { pengembangan ilmu pengetahuan }\end{array}$ \\
\hline & $\begin{array}{l}\text { b. Elemen } \\
\text { lanskap }\end{array}$ & $\begin{array}{l}\text { Tidak ada elemen yang } \\
\text { memiliki nilai pengetahuan/ } \\
\text { ilmiah }\end{array}$ & $\begin{array}{l}\text { Hanya beberapa elemen saja } \\
\text { yang memiliki nilai pengetahuan } \\
\text { yang tinggi }\end{array}$ & $\begin{array}{l}\text { Setiap elemen memiliki nilai } \\
\text { pengetahuan yang tinggi sehingga dapat } \\
\text { bermanfaat bagi pendidikan }\end{array}$ \\
\hline
\end{tabular}

Sumber: Harris dan Dines (1988) dan Australia ICOMOS (1999), dengan modifikasi 


\section{Hasil dan Pembahasan}

\subsection{Nilai Penting Estetika}

Nilai penting estetika dapat diukur berdasarkan kriteria arsitektur rumah, elemen lanskap, dan kesatuan elemen pembentuk lanskap. Berikut adalah penjelasan masing-masing kriteria:

\subsubsection{Arsitektur Rumah Tradisional}

Secara umum, rumah-rumah yang berada di Pekon Hujung masih berupa bangunan tradisional yang disebut sebagai Lamban Sabukh yang berarti rumah beratap ijuk. Rumah di Pekon Hujung merupakan rumah panggung yang memiliki ketinggian bervariasi dengan tiang dari kayu, tembok dari papan, dan atap dari ijuk. Menurut Koentjaraningrat (1979) dalam Putri, Y.Y., Gunawan, A., dan Arifin, N.H.S (2013), pemanfaatan material kayu ini merupakan ciri perkampungan kerajaan-kerajaan pesisir di Indonesia bagian barat yang diakibatkan karena seluruh kekuatan rakyat pada masa itu dikerahkan untuk pembangunan armada perdagangan. Sehingga rumah-rumah tinggal yang ada seluruhnya dibangun dengan material kayu.

Penataan ruang di dalam rumah umumnya dipengaruhi oleh faktor kekerabatan. Penataan ruang vertikal di dalam rumah tradisional umumnya terbagi menjadi tiga bagian, yaitu bagian bawah rumah (bah lamban), bagian tengah (badan lamban), dan bagian atas (panggakh) yang merepresentasikan kaki, badan, dan kepala bangunan.

Rumah-rumah tradisional juga merupakan bentuk adaptasi dan respon terhadadap lingkungan alam. Sebagian besar wilayah Kabupaten Lampung Barat terletak pada ketinggian yang berkisar antara $501 \mathrm{~m}$ 100m diatas permukaan laut yaitu sebesar $46,9 \%$ dari luas total wilayahnya (Badan Pusat Statistik Kabupaten Lampung Barat, 2019). Hal ini berimplikasi terhadap kondisi suhu lingkungan yang sejuk, dan relatif dingin pada malam hari. Berdasarkan penuturan pemuka adat Pekon Hujung, bentuk rumah dengan atap jerami yang tinggi dan dinding kayu memberikan rasa hangat pada malam hari di dalam rumah. Pemakaian material jerami umum dilakukan pada rumah-rumah tradisional kerena ringan, lentur, menyerap goncangan gempa, serta memberikan kehangatan pada malam hari (Widiati, 2016).

Berdasarkan hasil survei, terlihat banyak rumah yang mulai mengalami perubahan baik dari segi penggunaan bagian bawah rumah (bah lamban), perubahan detil fasad rumah, serta penambahan bagianbagian rumah (Lestari dan Fadhili, 2020). Meskipun demikian, pemugaran yang dilakukan tidak sepenuhnya menghilangkan gaya atau ornamen yang sudah melekat pada bangunan asli. Pada gambar 2A dan 2B dapat dilihat bentuk rumah tradisional yang masih menggunakan elemen dan material tradisional, sementara pada Gambar 2C dan 2D dapat dilihat rumah tradisional yang sudah dimodifikasi dengan bentuk yang lebih modern.

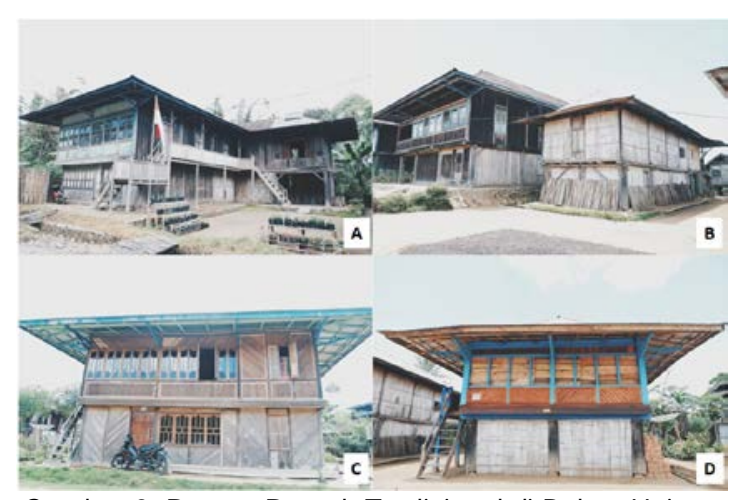

Gambar 2. Ragam Rumah Tradisional di Pekon Hujung

\subsubsection{Elemen Lanskap}

Lanskap Pekon Hujung didominasi oleh rumah-rumah tradisional atau lamban sabukh. Berdasarkan hasil pengamatan lapang, ditemukan bahwa telah terjadi perubahan dari bentuk dan material rumah. Beberapa rumah yang awalnya memiliki bah lamban yang tertutup, saat ini sudah ada yang dimodifikasi menjadi ruangan terbuka yang memiliki fungsi tertentu seperti ruang tamu. Selain itu, perubahan yang paling banyak terjadi adalah pemakaian material modern, dikarenakan masyarakat lebih mudah untuk 
mendapatkan bahan-bahan modern daripada bahan-bahan seperti kayu untuk bangunan dan ijuk untuk atap. Perubahan ini juga didukung oleh kemudahan akses dari dan menuju Pekon Hujung saat ini, dan mata pencaharian masyarakat yang beragam. Perubahan juga terjadi pada pola pembangunan Pekon Hujung, yang saat ini sudah meluas hingga 6 dusun dan tidak lagi mengikuti pola perkembangan yang linier. Selain rumah-rumah tradisional, salah satu elemen penciri Pekon Hujung yang masih ada hingga saat ini adalah walai atau lumbung padi (Gambar 3). Berdasarkan pengamatan lapang, masih ditemukan banyak walai di Pekon Hujung, baik yang dibangun sendiri atau dibangun berkumpul pada satu lokasi.

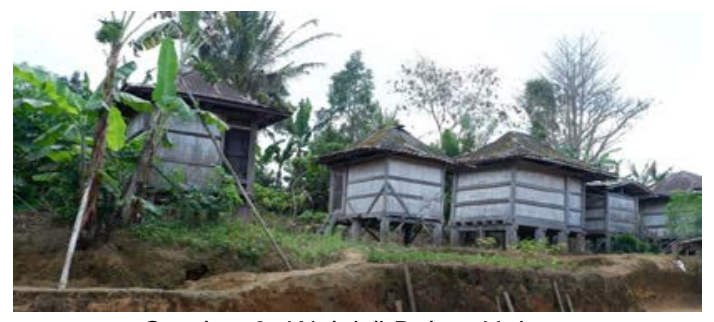

Gambar 3. Walai di Pekon Hujung

\subsubsection{Kesatuan Elemen Pembentuk Lanskap}

Seluruh elemen pembentuk lanskap di Pekon Hujung saling terintegrasi baik pada skala makro maupun pada skala mikro. Penggunaan lahan pada skala makro permukiman membentuk pola yang terintegrasi, terdiri dar area permukiman, area usaha perkebunan dan pertanian masyarakat, serta area fasilitas pekon yang terdiri dari sekolah, area peribadatan hingga pasar. Pusat permukiman yang pertama adalah pada dusun 1, kemudian berkembang hingga ke dusun 6 dengan pola linier dan pada perkembangannya menjadi berbaris ke belakang. Pada skala yang lebih kecil atau skala mikro, kesatuan elemen terlihat dari susunan rumah-rumah yang saling berdekatan dan nyaris tanpa pembatas satu sama lainnya. Halaman atau pekarangan umumnya dibiarkan kosong atau hanya ditanami tanaman pembatas di tepi batas kepemilikan rumah. Hal ini dikarenakan pekarangan masyarakat umumnya dimanfaatkan untuk menjemur hasil panen. Di antara rumah umumnya dapat ditemui walai, baik yang dibangun secara individu maupun secara berkelompok.

\subsection{Nilai Penting Sejarah}

Nilai penting sejarah terkait dengan tata guna lahan, keberadaan elemen lanskap, dan area serta tempat yang bersejarah. Elemen lanskap bersejarah yang masih ada hingga saat ini adalah dua lamban sabukh asLi yang masih terdapat di Pekon Hujung (Gambar 4a). Kedua lamban sabuk tersebut hingga saat ini belum mengalami banyak perubahan baik dari segi material maupun fungsinya, sehingga kedua lamban tersebut menjadi objek penting bagi masyarakat Pekoh Hujung. Selain lamban sabukh tersebut, berdasarkan penuturan pemangku adat setempat ada sebuah objek yang juga dianggap memiliki nilai sejarah yaitu sebuah batu besar yang disebut sebagai batu irau (Gambar 4b). Batu tersebut sudah ada sejak masyarakat datang ke area Pekon Hujung, dan tidak dapat dipindahkan sehingga dibiarkan pada posisinya hingga saat ini.

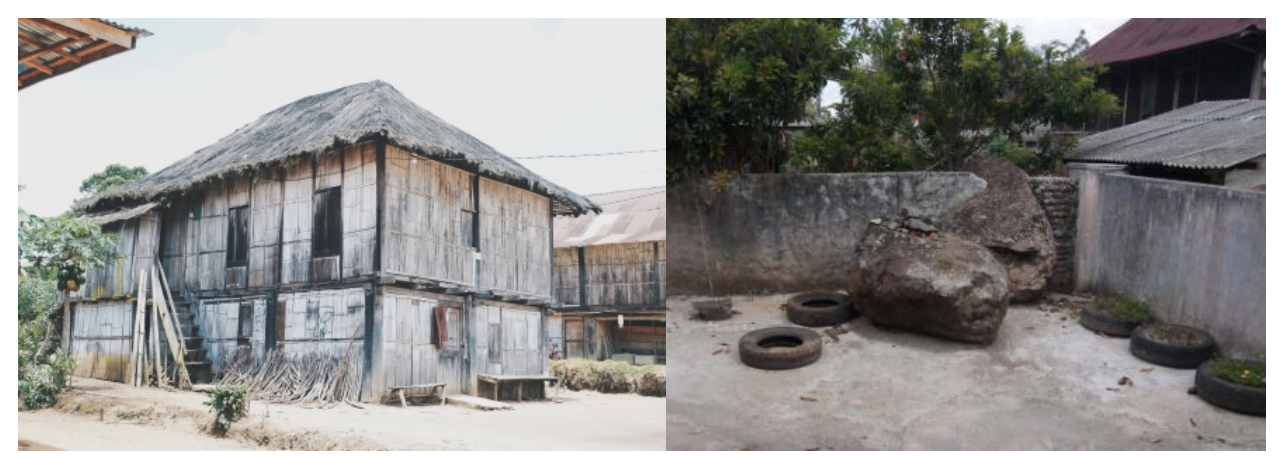

Gambar 4a. Lamban Sabukh, 4b. Batu Irau 


\subsection{Nilai Penting Sosial dan Spiritual}

\subsubsection{Area/Ruang}

Nilai penting sosial dan spiritual dapat diukur berdasarkan kriteria area atau ruang, norma atau aturan adat, serta tradisi budaya. Kegiatan kehidupan sehari-hari masyarakat Pekon Hujung terkait erat dengan area dan ruang permukiman. Aktivitas masyarakat sebagian besar dilakukan di dalam dan di sekitar ruang permukiman, baik dari kegiatan bertani dan berkebun hingga kegiatan sehari-hari. Aktivitas dimulai dari lingkup terkecil permukiman yaitu rumah, masyarakat Pekon Hujung umumnya memiliki rumah yang saling berdekatan dan tidak memiliki batas nyata dengan rumah tetangganya. Hal ini terjadi karena sebagian besar masyarakat di Pekon Hujung memiliki hubungan kekerabatan, dan cenderung suka untuk bersilaturahmi ke tetangganya. Berdasarkan hal tersebut, halaman rumah atau pekarangan juga merupakan elemen penting di dalam permukiman. Masyarakat umumnya menggunakan halaman untuk menjemur hasil panen berupa kopi. Sebagian halaman rumah milik masyarakat juga menjadi tempat menanam dan mengolah kopi (Gambar 5).

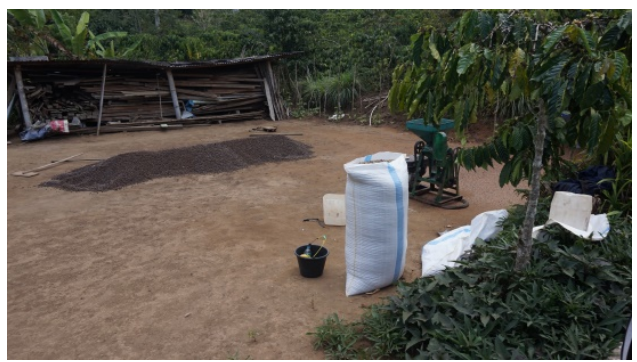

Gambar 5. Pengolahan Kopi di Halaman Rumah

\subsubsection{Norma/Aturan Adat}

Norma atau aturan adat yang masih dijalankan di Pekon Hujung adalah sistem kesultanan, dengan adanya pemangku adat sebagai pemimpin secara adat. Saat ini Pekon Hujung dipimpin oleh seorang Peratin, yang juga menjabat sebagai Kepala Pekon Hujung secara administratif. Kepemimpinan adat sudah ditentukan secara turun-temurun dengan urutan sebagai berikut: (1) Sultan; (2) Raja; (3) Raden/Khadin; (4) Batin; (5) Minak; (6) Itun; (7) Kimas (Gambar 6). Sistem musyawarah adat masih dilakukan di Pekon Hujung, semua masalah terkait pekon akan diselesaikan bersama dengan para pemangku adat. Masyarakat masih menjunjung tinggi sistem kesultanan dan menghargai sistem kepemimpinan secara adat.

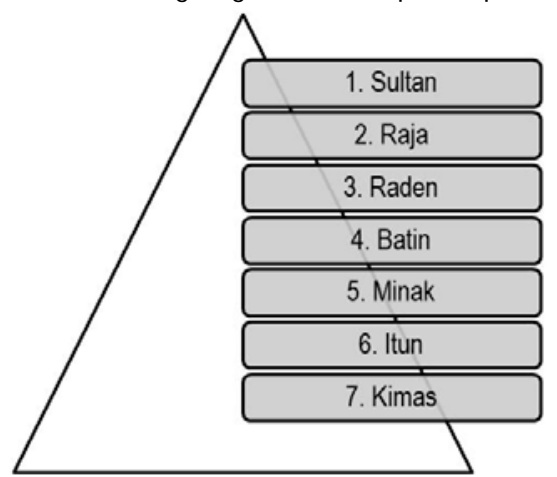

Gambar 6. Hierarki Kepemimpinan Adat di Pekon Hujung

\subsubsection{Tradisi/Budaya}

Masyarakat Pekon Hujung hingga saat ini masih melestarikan tradisi dan kebudayaan adat. Walaupun dalam proses pelaksanaannya saat ini sudah banyak kemudahan karena perkembangan zaman namun esensi nilai dari tradisi dan budaya yang dilaksanakan tidak berubah. Beberapa tradisi budaya yang masih dilaksanakan oleh masyarakat Pekon Hujung meliputi: sambatan yaitu upacara yang biasa dilakukan saat awal musim bertani; betegak yaitu upacara yang yang biasa dilakukan saat mendirikan rumah baru; ngumbai yaitu upacara yang dilakukan saat akhir masa panen sebagai bentuk syukur; begawi yaitu upacara 
yang dilakukan saat merayakan pernikahan; serta upacara-upacara lain yang meliputi aspek kehidupan seperti kelahiran, sirkumsisi, pertunangan, hingga upacara kematian. Namun ketika dilakukan penelitian tidak terdapat kegiatan tradisi/budaya yang sedang dilaksanakan di Pekon Hujung, sehingga tidak ada dokumentasi yang dapat disajikan.

\subsection{Nilai Penting Ilmiah}

Nilai penting ilmiah meliputi kriteria aktivitas dan elemen lanskap. Nilai penting ilmiah merupakan nilai yang terdapat di masyarakat yang memiliki potensi ilmu pengetahuan. Nilai penting ilmiah yang terdapat di dalam Pekon Hujung berupa bentuk rumah yang menyesuaikan dengan lingkungan serta pemanfaatan walai untuk menyimpan hasil panen. Struktur rumah di Pekon Hujung merupakan bentuk adaptasi terhadap lingkungan alam sekitar. Rumah-rumah tradisional di Pekon Hujung berupa rumah panggung dengan tiang penyangga setinggi kurang lebih $2 \mathrm{~m}$ merupakan bentuk adaptasi terhadap hewan buas yang dahulu masih banyak di daerah tersebut. Konstruksi tiang penyangga rumah yang saling terkait satu sama lain juga merupakan bentuk adaptasi terhadap bencana gempa bumi yang sering terjadi di kawasan Lampung Barat. Menurut Ibrahim, W. dan Nandang (2011), hal ini dikarenakan banguna tradisional dengan sistem pondasi tumpak (di atas tanah) dan beratap ijuk yang ringan memiliki fleksibilitas yang tinggi terhadap goyangan dan pergerakan bumi.

Selain itu bentuk rumah lama yang sebagian besar fasadnya tertutup dan hanya memiliki beberapa jendela kecil merupakan bentuk adaptasi terhadap suhu dingin pegunungan. Sebelum terjadi banyak perubahan, dahulu dapur berada di dalam rumah yang juga merupakan bentuk adaptasi terhadap suhu dingin pada malam hari. Elemen lanskap lain yang juga memiliki nilai ilmiah adalah walai. Lantai dan dinding walai biasanya terbuat dari bambu dan ijuk yang dipipihkan dan dibuat berlapis-lapis. Lapisan ini sengaja dibuat tebal untuk menghindari hama tikus masuk dan merusak hasil panen yang disimpan (Kemenbudpar, 2011). Selain itu, walai umumnya dibuat dengan tangga yang bisa dilepas-pasang, dengan tujuan untuk menghindari hama tikus.

\subsection{Pembobotan Nilai Penting}

Berdasarkan hasil penilaian terhadap empat kriteria nilai penting estetika, sejarah, sosial/spiritual/ serta ilmiah, maka dilakukan pembobotan signifikansinya (Tabel 2). Pembobotan ini dilakukan untuk menentukan karakter lanskap penting dari Pekon Hujung.

Tabel 2. Pembobotan Nilai Signifikansi Lanskap

\begin{tabular}{|c|c|c|c|}
\hline Nilai Penting & Aspek & Kriteria & Penilaian \\
\hline \multirow[t]{3}{*}{ Estetika } & Arsitektur rumah & $\begin{array}{l}\text { Didominasi }>50 \% \text { oleh rumah yang memiliki gaya arsitektur } \\
\text { tradisional dan keaslian }\end{array}$ & 3 \\
\hline & Elemen lanskap & Keaslian elemen baik bentuk, material, dan letaknya $50-75 \%$ & 2 \\
\hline & Integritas/unity & $\begin{array}{l}\text { Lanskap memiliki unity yang kuat dan karakter yang } \\
\text { harmonis dengan sekitarnya }\end{array}$ & 3 \\
\hline \multirow[t]{3}{*}{ Sejarah } & Land use & Terjadi perubahan penggunaan lahan $25-50 \%$ & 2 \\
\hline & Elemen lanskap & Terdapat 2-5 elemen bersejarah dengan umur $>50$ tahun & 2 \\
\hline & Area/ruang & $\begin{array}{l}\text { Tidak terdapat area atau tempat yang memiliki nilai sejarah } \\
\text { kejadian penting di masa lalu }\end{array}$ & 1 \\
\hline \multirow[t]{3}{*}{ Sosial/Spiritual } & Area/ruang & $\begin{array}{l}\text { Aktivitas sosial budaya masyarakat masih berjalan namun } \\
\text { area atau ruang untuk beraktivitas sudah tidak ada atau } \\
\text { sebaliknya }\end{array}$ & 2 \\
\hline & Norma/aturan adat & $\begin{array}{l}\text { Norma atau aturan adat masih sepenuhnya dijalankan oleh } \\
\text { masyarakat }\end{array}$ & 3 \\
\hline & Tradisi budaya & $\begin{array}{l}\text { Masyarakat umumnya masih melakukan tradisi } \\
\text { ritual adat pada acara tertentu }\end{array}$ & 3 \\
\hline \multirow[t]{2}{*}{ Ilmiah } & Aktivitas & $\begin{array}{l}\text { Terdapat kearifan lokal yang dipertahankan dan berpotensi } \\
\text { bagi pengembangan ilmu pengetahuan }\end{array}$ & 3 \\
\hline & Elemen lanskap & $\begin{array}{l}\text { Setiap elemen memiliki nilai pengetahuan yang } \\
\text { tinggi sehingga dapat bermanfaat bagi pendidikan }\end{array}$ & 3 \\
\hline Total & & & 27 \\
\hline
\end{tabular}


Pembobotan menunjukan hasil skor nilai penting sebesar 27, dan berdasarkan perhitungan nilai signifikansi termasuk kedalam kategori tinggi. Secara umum lanskap Pekon Hujung memiliki ciri khas dan karakter tersendiri, dimana elemen-elemen pendukungnya lanskapnya serta masyarakatnya masih hidup dan menjalankan nilai-nilai budaya yang ada sejak dahulu. Lanskap Pekon Hujung merupakan lanskap budaya yang memiliki nilai penting dan kearifan setempat yang masih dapat dipelajari dan diterapkan dalam kehidupan di masa kini.

\section{Simpulan}

Lanskap permukiman Pekon Hujung memiliki nilai signifikansi sebesar 27 dan termasuk kedalam kategori nilai signifikansi tinggi. Hal tersebut mengindikasikan pentingnya pelestarian lanskap permukiman Pekon Hujung. Lanskap budaya yang memiliki nilai penting, merupakan kebanggaan dan idenititas bangsa yang harus dilestarikan sehingga dapat memberikan manfaat yang berkelanjutan bagi generasi saat ini hingga generasi yang akan datang. Hasil penilaian yang menjadi karakter kunci dalam lanskap permukiman Pekon Hujung adalah rumah tradisional Lamban Sabukh, walai, serta kegiatan dan aktivitas budaya yang masih dilakukan oleh masyarakat.

\section{Ucapan Terima Kasih}

Ucapan terima kasih penulis tujukan kepada Hibah Kemenristek-BRIN / Simitabmas Tahun 2020 yang telah mendanai penelitian ini melalui Penelitian Dosen Pemula Tahun 2020.

\section{Daftar Pustaka}

Allindani. 2007. Studi Potensi Lanskap Bersejarah untuk Pengembangan Wisata Sejarah di Kota Mataram. Skripsi (unpublished). Institut Pertanian Bogor.

Badan Pusat Statistik Kabupaten Lampung Barat. 2020. Kabupaten Lampung Barat dalam Angka. BPS Kabupaten Lampung Barat, Lampung Barat.

Direktorat Tradisi, Direktorat Jenderal Nilai Budaya Seni dan Film. 2011. Arsitektur Tradisional Daerah Lampung. Balai Pustaka, Jakarta.

Harris CW, Dines NT. 1988. Time-Saver Standards for Landscape Architecture: Design and Construction Data. The McGrawHill Companies, New York.

Heritage Council of Victoria. 2009. Landscape Assessment Guidelines for Cultural Heritage Significance. Heritage Council of Victoria, Melbourne.

Ibrahim, W. dan Nandang. 2011. Arsitektur Tradisional Kenali Salah Satu Kearifan Lokal Daerah Lampung. Jurnal Rekayasa 15(1):59-66.

International Council on Monuments and Sites. 1999. The Burra Charter: The Australia ICOMOS Charter for Places of Cultural Significance. Burra: Australia ICOMOS.

Lestari dan Fadhili. 2020. Tipologi Grid Kolom Pada Lamban Pekon Hujung di Lampung Barat. Jurnal Arsitektur 10(1):1-6.

Malim, D.D.L.O., Sumantri, I., Tahara, T. 2019. Inventarisasi dan Pengembangan Potensi Cagar Budaya Kota Baubau. Kainawa: Jurnal Pembangunan \& Budaya 1(1):1-15.

Pemerintah Kabupaten Lampung Barat. 2012. Peraturan Daerah Kabupaten Lampung Barat Nomor 1 Tahun 2012 tentang Rencana Tata Ruang Wilayah Kabupaten Lampung Barat Tahun 2010-2030. Pemkab Lampung Barat, Liwa.

Pratiwi, R. A., \& Gunawan, A. 2017. Study of Lampungnese Traditional Home Garden Design. IOP Conference Series: Earth and Environmental Science 91(1):1-8. https://doi.org/10.1088/1755$\underline{1315 / 91 / 1 / 012024}$

Putri, Y.Y., Gunawan, A., dan Arifin, N.H.S. 2013. Kajian Lanskap Permukiman Tradisional Masyarakat Lampung Saibatin di Pekon Kenali, Lampung Barat. Jurnal Permukiman 8(3):153-167.

Widiati, I.R. 2016. Kajian Struktur Rumah Tradisional Papua (Honai). Jurnal IImiah Teknik dan Informatika, 1(1):18-23. 